\title{
Protein-rich mixtures \\ for human consumption based on fish flour, sunflower presscake meal, dried skim milk and wheat flour
}

\author{
By DIGNA BALLESTER, ITA BARJA, E. YANEZZ AND G. DONOSO* \\ Laboratory of Nutrition, School of Public Health, University of Chile
}

(Received ${ }_{5}$ September I967-Accepted I Fanuary 1968)

\begin{abstract}
I. The quality of the protein in five high-protein mixtures intended for human consumption and made from materials that are available in Chile is reported.

2. The ingredients were fish flour, bread, wheat (Triticum sativum Lam.) flour, roasted whole wheat flour, a wheat flour made from a variety of durum wheat ( $T$. durum Desf.), skim milk and sunflower presscake, mixed in different proportions.

3. The net protein utilization when fed to rats in diets at the $10 \%$ level of protein calories gave values in the range $66-76$, which compare well with that (67), found for Incaparina, an all-vegetable mixture produced by the INCAP Group and used in Colombia, and are higher than the values ( 55 and 56 ) obtained for Peruvitas, which are mixtures made up basically from cottonseed and quinoa reinforced with dried skim milk.

4. The protein values of the mixtures, expressed as net dietary protein calories $\%$, were calculated from their biologically determined net protein utilization (operative), and gave values that ranged from 10.5 to $12 \cdot 8$, which are higher than the recommended values in diets for infants and toddlers.
\end{abstract}

In Chile two types of malnutrition are generally recognized in children, marasmus and kwashiorkor (Mönckeberg, I966), but the incidence of clinically evident cases of the two syndromes is very low by comparison with the number of children who show retarded physical development for their age and who are simply not receiving enough food for socio-economic reasons (Donoso \& Mönckeberg, 1965).

Foods that determine the cost of an adequate diet for children are generally those that have a high content of good-quality protein. This is why the possibility of using protein-rich mixtures made from locally available sources as a means of lowering the cost of providing an adequate protein intake has been given increasing attention in many parts of the world (Bressani \& Behar, I964).

We have studied mixtures based on wheat flour, fish flour, sunflower presscake and skim-milk powder as a first step in the formulation of protein-rich foods that can either be offered commercially to the community or be used in the already existing mass feeding programmes sponsored by the National Health Service or other government agencies (Santa María, Planella \& Silva, r966).

In this paper we present values for the quality of the protein in the mixtures measured as net protein utilization when fed at the $10 \%$ level of protein calories $\left(\mathrm{NPU}_{\mathrm{op}}\right)$. Protein values of the mixtures, calculated from their biologically determined net protein utilization and expressed as net dietary protein calories ( $\mathrm{NDpCal} \%$ ) are also given (Platt, Miller \& Payne, I961). For comparative purposes results obtained with

* Present address: Food and Nutrition Institute of Iran, Tehran, Iran. 
Incaparina and Peruvita (sweet and salt varieties), which are protein-rich mixtures for human consumption developed in Guatemala and Colombia, and Peru respectively, are also included.

\section{EXPERIMENTAL}

\section{Materials}

The fish flour was a defatted, deodorized product manufactured in Quintero, Chile, from a local hake, Merluccius gayi (Yáñez \& Donoso, 1964).

Sunflower presscake meal was a by-product of the edible-oil industry, which uses a combination of expeller and solvent extraction with hexane-heptane. The process involves cooking the oilseeds at $80-100^{\circ}$ for $\mathrm{I} h$ in the presence of $8-10 \%$ moisture. The residual solvent is eliminated by steaming $\left(80-100^{\circ}\right.$ for $\left.2 \mathrm{~min}\right)$.

Dried skim milk was a sample obtained from a local industry.

Wheat flour was of two types: one untreated type of $80 \%$ extraction and one made from a variety of Triticum durum Desf., known locally as 'harina candeal'. Attention should be drawn to the fact that flour made from the durum variety of wheat has a considerably higher protein content than the ordinary bread wheat (T. sativum Lam.) flour ( $\left.5_{5} \cdot v^{*} .93\right)$, which makes its inclusion in protein-rich mixtures very useful. This type of wheat is generally used in the manufacture of the 'semolina' employed in the making of the 'pasta' products (such as noodles, spaghetti and canneloni); its price does not differ from that of the ordinary wheat flour.

Roasted wheat meal was finely ground, roasted whole grain.

\section{Methods}

Water, ash, ether extract, crude fibre and protein were determined according to the methods described by Schmidt-Hebbel (1966). Net protein utilization was determined in weanling rats according to the method of Miller \& Bender (1955) in diets in which protein supplied I0 $\%$ of the calories $\left(\mathrm{NPU}_{10}\right)$. NPU was also determined in the mixtures as such, i.e. NPU operative $\left(\mathrm{NPU}_{\mathrm{op}}\right)$. Calorie content was determined in a ballistic bomb calorimeter (Miller \& Payne, r959).

Chemical scores were calculated by the FAO (1957) method. Protein calories \% $(P)$ were calculated by the method of Miller \& Payne (Ig63). Protein values (as NDpCal \%) were calculated by multiplying $\mathrm{NPU}_{\mathrm{op}}$ by $P$, according to the method of Platt $e t$ al. (1961).

\section{RESULTS}

Table I shows that defatted fish flour produced in the plant at Quintero as well as the sunflower presscake meal had a high protein concentration which makes their use in protein-rich mixtures of potential interest.

It is noteworthy that flour made from the durum variety of wheat had a considerably higher content of protein and of ether-extractable substances than ordinary wheat flour.

Table 2 shows that the proposed protein-rich mixtures (MM) had a high protein content, ranging from 25.3 to $34.9 \%$, similar to Peruvitas and Incaparina (Table 3 ). 
The crude-fibre content of MM mixtures varied from 2.6 to $4.3 \%$. Energy content fell within a very narrow range, from 3 I 5 to $337 \mathrm{kcal} / \mathrm{roO} \mathrm{g}$.

Table 4 shows the determined values for $\mathrm{NPU}_{\text {op }}$ and $\mathrm{NPU}_{10}$ for the different mixtures and for Incaparina and Peruvita. Values for gluten and casein are included for re-

Table I. Gross chemical composition $(\mathrm{g} / \mathrm{1} 00 \mathrm{~g})$ of material used in the formulation of the protein mixtures

\begin{tabular}{|c|c|c|c|c|c|}
\hline Material & Water & Ash & $\begin{array}{l}\text { Protein } \\
(\mathrm{N} \times 6.25)\end{array}$ & $\begin{array}{l}\text { Ether } \\
\text { extract }\end{array}$ & $\begin{array}{l}\text { Crude } \\
\text { fibre }\end{array}$ \\
\hline Fish flour & $6 \cdot 9$ & $2 I \cdot I$ & $70 \cdot 5$ & 0.2 & - \\
\hline Sunflower presscake meal & $6 \cdot 2$ & $8 \cdot 5$ & $46 \cdot 6$ & $4 \cdot 3$ & $8 \cdot 9$ \\
\hline Dried skim milk & 4.0 & 7.8 & 33.6 & $2 \cdot 3$ & - \\
\hline Roasted whole wheat meal & $4 \cdot 2$ & $2 \cdot 2$ & $13 \cdot 4$ & $\mathbf{I} \cdot 9$ & 0.9 \\
\hline Durum wheat flour & $12 \cdot 6$ & $4 \cdot 2$ & $15 \cdot 3$ & 4.9 & $\circ$ \\
\hline Wheat flour & $6 \cdot 3$ & 0.6 & $9 \cdot 3$ & $\mathrm{I} \cdot 4$ & 0.5 \\
\hline
\end{tabular}

Table 2. Gross chemical composition ( $\mathrm{g} / \mathrm{1} 00 \mathrm{~g}$ ) and calorie value of the different protein mixtures

\begin{tabular}{|c|c|c|c|c|c|c|c|}
\hline Mixture & Water & Ash & $\begin{array}{l}\text { Protein } \\
(\mathrm{N} \times 6.25)\end{array}$ & $\begin{array}{l}\text { Ether } \\
\text { extract }\end{array}$ & Fibre & $\begin{array}{c}\text { Non- } \\
\text { nitrogenous } \\
\text { extract* }\end{array}$ & $\begin{array}{c}\text { Calories } \\
(\mathrm{kcal} / \mathrm{I} 00 \mathrm{~g})\end{array}$ \\
\hline MM I8 & $9 \cdot 4$ & $8 \cdot 0$ & $3 I \cdot 8$ & 3.9 & $2 \cdot 6$ & $44^{\prime} 3$ & 318 \\
\hline MM 21 & $8 \cdot 3$ & $6 \cdot 1$ & $34 \cdot 3$ & $\mathbf{I} \cdot 8$ & $2 \cdot 9$ & $46 \cdot 6$ & 337 \\
\hline MM 22' & $6 \cdot 3$ & $5 \cdot 2$ & $25 \cdot 3$ & 3.7 & $3 \cdot 2$ & $56 \cdot 3$ & 330 \\
\hline MM $23^{\prime \prime}$ & $8 \cdot 2$ & $8 \cdot 7$ & $34 \cdot 9$ & $2 \cdot 4$ & $2 \cdot 6$ & $43 \cdot 2$ & 315 \\
\hline MM 25 & $6 \cdot 5$ & $6 \cdot 9$ & $30 \cdot 4$ & 3.5 & $4 \cdot 3$ & $48 \cdot 4$ & 318 \\
\hline
\end{tabular}

Composition (g): MM I8: fish flour 15, sunflower presscake meal 30, wheat flour $55 ;$ MM 2 I: fish flour I5, sunflower presscake meal 30, dried skim milk Io, wheat flour 45; MM 22': fish flour 8, sunflower presscake meal 25, roasted wheat flour 67; MM 23": fish flour I 5, sunflower presscake meal 30, dried skim milk I $_{5}$, durum wheat flour 40; MM 25: sunflower presscake meal 50, dried skim milk 25, roasted wheat flour 25 .

* Calculated by difference.

Table 3. Gross chemical composition of Incaparina I $_{5}$ and Peruvita (salted and sweet)

\begin{tabular}{|c|c|c|c|c|}
\hline & $\begin{array}{l}\text { Water } \\
(\mathrm{g} / \text { 100 } \mathrm{g})\end{array}$ & $\begin{array}{c}\text { Ash } \\
(\mathrm{g} / 100 \mathrm{~g})\end{array}$ & $\begin{array}{l}\text { Protein } \\
\mathrm{N} \times 6.25 \\
(\mathrm{~g} / 100 \mathrm{~g})\end{array}$ & $\begin{array}{c}\text { Ether } \\
\text { extract } \\
(\mathrm{g} / \mathrm{I} 00 \mathrm{~g})\end{array}$ \\
\hline Peruvita* (salted) & $5 \cdot 8$ & II.7 & 34.9 & $4 \cdot 8$ \\
\hline Peruvitat (sweet) & $5 \cdot 9$ & 5.6 & $31 \cdot 0$ & $4^{\prime} 4$ \\
\hline Incaparinat I 5 & $6 \cdot 6$ & $4 \cdot 5$ & $24 \cdot I$ & $4 \cdot 2$ \\
\hline
\end{tabular}

* Composition (g): cottonseed meal 56 ; quinoa (Chenopodium quinoa) 30 ; skim-milk powder $4 ; \mathrm{NaCl}$ $6.7 ; \mathrm{CaCO}_{3} \mathrm{x}$; thiamine 0.002 ; riboflavine 0.003 ; vitamin $\mathrm{A} 0.003$.

+ Composition (g): cottonseed meal $5 \circ$; quinoa 24 ; skim-milk powder 4 ; sucrose $19 \cdot 6$; $\mathrm{CaCO}_{3} \mathrm{x}$; thiamine 0.002 ; riboflavine 0.003 ; vitamin A 0.003 .

$\ddagger$ Composition $(\mathrm{g})$ : maize meal 58 ; soya bean $\mathrm{I} 9$; cottonseed meal 19 ; torula $3 ; \mathrm{CaCO}_{3} \mathrm{I}$; vitamin A 500000 i.u.

ference. Protein values (NDpCal \%) and chemical scores are also given. The NPU of the mixtures was uniformly high, comparing well with that for casein. They were of the same order as, or slightly higher than, the value obtained for Incaparina. 
The protein concentration of Incaparina was very similar to that of mixture MM $2 \mathbf{2}^{\prime}$, and the rest of the mixtures studied contained protein at about the same level as the Peruvita mixtures (Tables 2 and 3 ).

Table 4. Protein calories as a percentage total calories (P), net protein utilization $\left(N P U_{o p}\right)$, net dietary protein calories \% (NDpCal \%), net protein utilization at $10 \%$ protein calories $\left(N P U_{10}\right)$ and chemical score of mixtures based on sunflower presscake meal, fish flour and different cereal products, and Incaparina and Peruvita

\begin{tabular}{|c|c|c|c|c|c|}
\hline & $P$ & $\mathrm{NPU}_{\mathrm{op}}$ & NDpCal \% & $\mathrm{NPU}_{10}$ & $\begin{array}{l}\text { Chemical } \\
\text { score }\end{array}$ \\
\hline MM I 8 & $35^{\circ} 0$ & 35 & $12 \cdot 3$ & 76 & $7 \mathrm{I}$ \\
\hline MM 2I & 37.0 & $3 I$ & II -5 & 67 & 73 \\
\hline MM 22' & $27 \cdot 0$ & 39 & 10.5 & 71 & 71 \\
\hline MM $23^{\prime \prime}$ & $40^{\circ} 0$ & 32 & $12 \cdot 8$ & 75 & 74 \\
\hline $\mathrm{MM}_{25}$ & $35^{\circ} \circ$ & 30 & 10.5 & 66 & 67 \\
\hline \multicolumn{6}{|l|}{ Peruvita } \\
\hline Salted & $39^{\circ} 0$ & 25 & 9.7 & 55 & 67 \\
\hline Sweet & $33^{\circ} \circ$ & 25 & $8 \cdot 3$ & 56 & 67 \\
\hline Incaparina 15 & 29.7 & 33 & $9^{\cdot 8}$ & 67 & 65 \\
\hline Casein & $\cdots$ & - & $\div$ & $71 \cdot 2 \pm 2 \cdot 1 *$ & - \\
\hline Gluten & - & - & - & $39^{\circ} 8 \pm I \cdot 5^{*}$ & - \\
\hline
\end{tabular}

\footnotetext{
* Standard deviation in a series of six determinations (M. A. Tagle, unpublished results).
}

\section{DISCUSSION}

Fish flour and sunflower presscake meal seemed of interest to us because they are available or can readily be made available in important quantities in Chile and they are good sources of high-quality protein (Yáñez \& Donoso, 1964; Yáñez, Pak \& Donoso, 1965). The sunflower meal used has a bland, sweetish and slightly malty flavour and leaves no aftertaste. However, the high crude fibre content of the sunflower presscake meal may make it objectionable, especially to the very young, unless it can be reduced to acceptable levels. Infants (4-6 months of age) showed no gastro-intestinal disturbances during feeding trials from I month to 6 weeks duration using MM I8.

The inclusion of milk in protein-rich mixtures can considerably increase the biological utilization of poorer proteins, making these mixtures 'milk extenders'. In our experiment the inclusion of $25 \%$ dried skim milk in mixture MM 25 resulted in a $\mathrm{NPU}_{10}$ value of 66 , which is considerably higher than that of its vegetable ingredients, i.e. sunflower presscake meal $\left(\mathrm{NPU}_{10}=52\right)$ (Yáñez et al. I965) $^{6}$ and roasted wheat flour $\left(\mathrm{NPU}_{10}=34\right)$ (Ballester, Tagle \& Donoso, 1962).

The low $\mathrm{NPU}_{10}$ values found for Peruvita were not in agreement with the calculated chemical scores. It is possible that the cottonseed meal used in its manufacture had suffered heat damage. The protein value of all the mixtures studied was quite high and, if the mixtures were used as the only food, would be above the recommendations of Platt et al. (I96I) for infants and toddlers. However, a value of over Io NDpCal \% would seem desirable if a mixture is intended as a protein supplement in diets that are mainly starchy.

Protein-rich mixtures can also be used as a separate food. Such is the case with 
mixture MM 22', which is intended not as a protein supplement but rather as a replacement for roasted whole wheat meal. Roasted whole wheat meal is much used by the lower income groups. It is made into a gruel by the addition of cold water and eaten uncooked with a little sugar. This gruel is known as 'ulpo' (ool-paw) and is much liked by toddlers and schoolchildren. Roasted whole wheat meal has the advantage of a good masking capacity, which is especially important when fish flour is added to the mixture. Tests with toddlers (Yáñez, Barja, Mönckeberg, Maccioni \& Donoso, 1967) showed that the acceptability of such an enriched gruel was very much the same as that of one made with the ordinary ingredients.

The fortification of the proposed mixtures with a vitamin-mineral preparation is, of course, very desirable, and would not raise the cost of the finished product to any considerable extent.

We are grateful to Compañia Productora Nacional de Aceites, S.A., for providing us with the sunflower meal and to Lechera del Sur, S.A., for supplying the milk used in these experiments.

\section{REFERENCES}

Ballester, D., Tagle, M. A. \& Donoso, G. (1962). Nutr. Bromatol. Toxicol. 1, 235.

Bressani, R. \& Behar, M. (1964). Proc. int. Congr. Nutr. vil. Edinburgh, 1963, p. I 8 1.

Donoso, G. \& Mönckeberg, F. (1965). Revta chil. Pediat. 36, 301.

FAO (1957). F.A.O. nutr. Stud. no. I6.

Miller, D. S. \& Bender, A. E. (1955). Br. F. Nutr. 9, 382.

Miller, D. S. \& Payne, P. R. (1959). Br. $¥$. Nutr. r3, 50т.

Miller, D. S. \& Payne, P. R. (I963). F. theor. Biol. 5, 398.

Mönckebcrg, F. (1966). Nutr. Bromatol. Toxicol. 5, 3 I.

Platt, B. S., Miller, D. S. \& Payne, P. R. (196I). In Recent Advances in Clinical Nutrition. [J. F. Brock, editor.] London: J. and A. Churchill Ltd.

Santa María, J. V., Planella, I. \& Silva, A. (1966). Nutr. Bromatol. Toxicol. 5, 107.

Schmidt-Hebbel, H. (1966). In Química y Tecnologia de los Alimentos. Santiago, Chile: Editorial Salesiana.

Yáñez, E., Barja, I., Mönckeberg, F., Maccioni, A. \& Donoso, G. (I 967). Fd Technol., Lond. (In the Press.)

Yáñez, E. \& Donoso, G. (I964). Nutr. Bromatol. Toxicol. 3, 43.

Yáñez, E., Pak, N. \& Donoso, G. (1965). Nutr. Bromatol. Toxicol, 4, 136. 